\title{
NEW LIGHT ON THE PRODUCTION OF MARBLE VESSELS FROM SMINTHEION
}

\author{
Davut KAPLAN
}

\begin{abstract}
Anahtar Kelimeler: Troas $\bullet$ Smintheion $\bullet$ mermer kap $\bullet$ vazo üretimi $\bullet$ teknik
\end{abstract}
Keywords: Troad $\bullet$ Smintheion $\bullet$ marble bowl $\bullet$ vessel production $\bullet$ technic

\section{Özet:}

Bu çalş̧ma Antik Troas Bölgesi'nde Apollon Smintheus kutsal alanında 2006 yilında gerçekleştirilen arkeolojik kazılarda ele geçen bir mermer kap parçasını üretim tekniği açısından incelemeyi amaçlar. Hellenistik ve Roma dönemlerinde çok yaygın olarak kullanılan üç çıkıntı tutamak ve bir akıtacağa sahip bir mermer kaba ait olan bu parçanın üretim artığını veya bitmemiş bir örneği temsil ettiği anlaşılmaktadır. Bu tür mermer kapların Hellenistik ve Roma dönemlerinde kozmetik amaçlarıyla toz boyayı yağla karıştırmada kullanıldığı ve özelikle mezarlarda ölü hediyesi olarak karşımıza çıktığı görülmektedir. Bu tür kapların daha önce nasıl üretildiği konusunda arkeolojik bilgilerimizin az olduğu göz önüne alındığında bitmemiş bu örneğin üzerinde yer alan ölçüm veya matematiksel oranlamaları gösteren pergel izlerinin ele geçmesi dönem arkeolojisi için yeni bir katkı sayılabilir.

\begin{abstract}
:
This study examines a fragment of a distinctive shallow marble bowl of ledge-lug type identified at the sanctuary of Apollo Smintheus during the archeological excavations undertaken in 2006. The surface of the fragment interestingly bears incised traces showing the use of ruler and compass. This fragment with tool marks is important because it illuminates us on the stages of production of such vessels. This type of bowl was a characteristic feature of Hellenistic and Roman periods. Such marble bowls with three ledge lugs and one spout were often used to crush pigment in antiquity. The frequent recovery of such shallow marble bowls in mortuary contexts seems to indicate that they were also deposited in burials to accompany their owners. In light of minimal number of evidence about the production of such marble bowls, it is hoped that this specimen from Smintheion will enhance our understanding of the tools used and techniques adopted in their production.
\end{abstract}

This modest essay aims to examine the fragment of an unfinished shallow marble bowl with three ledge lugs and a spout found during the course of the 2006 excava- tion season at Smintheion (Gülpınar) in the Troad $^{1}$. The most important feature of this

1 I thank to C. Özgünel for allowing me to publish this artifact from Smintheion. 
unfinished shallow marble vessel fragment is that it has the traces of workmanship showing various tool marks associated with the use of a compass and pointed metal tool. The use of compass was previously unknown to us when the production of marble vessels is concerned. This fragment was found among the fill of the Roman water reservoir near the Apollo Smintheus temple in the Troad. The structure in which it was found dates to a period sometimes in the third century A.D., and the fill recovered from this structure contained remains dating from the Hellenistic to the Byzantine periods. Thus, it is not possible to date this artifact with certainty. This type of shallow marble vessel is a characteristic feature of the Hellenistic and Roman periods. Stylistically comparable shallow vessels with ledge lugs have previously been attested in the third millennium B.C. in the Aegean world ${ }^{2}$ (fig. 1). They are particularly common during the Hellenistic and Roman periods through the Aegean and eastern Mediterranean world. For example, such marble shallow vessels are known to us from Miletus, Priene, Pergamon, Assos, Xanthos, and $\mathrm{Pa}$ tara in Asia Minor, Olynthus and Corinth in the Greek Mainland, Salamis and Kition on Cyprus, as well as Doura-Europos in Syria ${ }^{3}$. Archaeological evidence from the Troad demonstrates that these marble bowls were also common in this region, since at least twelve complete such vessels have previ-

\footnotetext{
Getz-Gentle 1996; Takaoğlu 2004.

Robinson 1952, 122-123; Cumont 1926, 255; Robinson 1930, 416, fig. 102; Deonna 1938, 106; Davidson 1952, 122; Demargne 1958, 67; Chavane 1975: 12; Parlasca 1983, 151; Stuppereich 1990, 28; Wiegand - Schrader 1904, 376; Pinkwart 1984, 109; Korkut 2004, 233; Hiesel 1967, 92; Tolle-Kastenbein 1974, 120, 167; Salles - Chavane 1993, 335; Hoffelner 1996, 45.
}

ously been found there ${ }^{4}$. At least four of them were found in association with pestles made from the same marble as the vessels. For example, those complete examples from the Dardanos tumulus, the Calvert collection, and the Assos excavations are important to obtain a better picture of these distinctive marble vessels of nonutilitarian character. Most of them are carved in the usual fine grained yellowishwhite marble. Visual examinations of the marble raw materials points to a single source. Although they are similar in terms of style, they differ from each other in terms of decoration and size. They vary in diameter from a diminutive $9 \mathrm{~cm}$ to a midsize $17.5 \mathrm{~cm}$. It also seems that the Troadic examples were commonly used in mortuary contexts as the possession of death. Such vessels as possession of death during life time were subsequently accompanied him or her after the death in the burials. It is likely that these shallow bowls were used in conjunction with ritual paint during the funerary rites. They were evidently used to pulverize the coloring matters so that they could be mixed with water or oil, perhaps before application to the skin of the deceased or the mourners. Such shallow bowls filled with pigment might have also been placed in the burials in order to be used in the afterlife. A marble vessel still bearing the vivid traces of pink pigment has been found from the Dardanos tumulus in the Troad to demonstrate the use and function of such objects. Likewise, roman burials at Patara in Lycia also yielded a series of such vessels along with pestles lying near them ${ }^{5}$.

\footnotetext{
4 Tombul 2006, 254; see also Deonna 1938, 111. 5 Korkut 2004, 239 res. 7.
} 
Previously, we did not know much about how such artifacts were manufactured and what kinds of tools were used and how they were used (figs. 2-3). The exterior of the marble vessels was strikingly finely refined first before its interior was hollowed out. It seems that the top of the preform or roughly-shaped vessel was outlined by the use of a compass and a ruler in order to emphasize the ledge lugs and the spout. After two circles showing the outer and inner edge of the rim of the vessel were incised, the craftsman emphasized the lugs asymmetrically by incising diagonally crossing contours. Four horizontal projections for lugs were roughly shaped opposite to one another on the upper part. One of the four ledge lugs were then turned in to a spout. Then, craftsman started to hollow out of its interior through pecking with a metal pointed tool. We know surely that this was done so, since this manufacturing error from Smintheion was broken at this stage of manufacture. This also contrasts with what we know about the manufacture of vessels. It is a general pattern that craftsman or craftswoman hollows out the interior of the vessel before the exterior is finely refined. Moreover, a primitive lathe-turning tool was often preferred during the Hellenisitic and Roman times to hollow out the interiors of such marble vessels. The fact that the vessel in question was shallow might have been one reason why a pointed tool was used, which unavoidably led to a breakage. This stage of production was probably the most risky part of marble vessel making process. Marble is not a hard stone to work but this does not mean that it is very easy to transform a block of marble into the intended form. Thus, it requires a patience, as well as skill and energy to transform a raw material into a final product.

This new datum from Smintheion contributes to our knowledge of manufacture of Hellenistic and Roman marble vessels of non-utilitarian character. The recovery of additional finished comparable marble shallow vessels with ledge lugs may also imply that they were also offered to the sanctuary of Apollo Smintheus. The recovery of this unfinished example at the sanctuary area seems can be used in favor of the argument that these marble vessels were actually manufactured in various parts of the Troad. This means that they were not to be viewed simply as imports arrived through trade. The idea of workshop specialized on marble vessels making at the sanctuary of Apollo Smintheus is attractive, since there is ample evidence to prove the presence of craftsmen working for sacred spaces in antiquity. More archaeological evidence is surely needed to demonstrate such theory. It is hoped that more evidence will be revealed about the aspects of marble working, including their production and consumption both at Smintheion and in the Troad.

Davut Kaplan (M.A.)

Ankara University

Faculty of Letters

Department of Archaeology

06100 Sihhiye/Ankara

e-mail: davut_kaplan@yahoo.com 


\section{List of Figures:}

Figure 1. Map locating major sites with marble bowls with three

Ledge lugs and a spout

Figure 2a-c. Various views of the preserved part of the unfinished bowl

Figure 3. Upper view of the fragment showing the use of compass and ruler in order to obtain a true mathematical ratios 


\section{BIBLIOGRAPHY}

Aston 1994

Chavane 1975

Cumont 1926

Davidson 1952

Demargne 1958

Deonna 1938

Getz-Gentle 1996

Hiesel 1967

Hoffelner 1996

Korkut 2004

Parlasca 1983

Pinkwart 1984

Robinson 1930

Salles - Chavane 1993

Stuppereich 1990

Takaoğlu 2005

Tombul 1996

Tölle-Kastenbein 1974

Wiegand - Schrader 1904
B. G. Aston, Ancient Egyptian Stone Vessels, Studen zur Archaologie und Geschichte Altagyptens 5 (1994).

M. J. Chavane, Les Petits Objects, Salamine de Chypre 6 (1975).

F. V. M. Cumont, Fouilles de Doura-Europos 1922-1923 (1926).

G. R. Davidson, Corinth XII, The Minor Objects (1952).

P. Demargne, Les Piliers funéraires. Fouilles de Xanthos I (1958).

W. Deonna, Le Mobilier Délien. Délos XVIII (1938).

P. Getz-Gentle, Stone Vessels of the Cyclades in the Early Bronze Age (1996).

G. Hiesel, Samische Steingeräte (1967).

K. Hoffelner, Die Sphinxsäule. Votiveträger, Altäre und Steingeräte, AltAgina II.4 (1996).

T. Korkut, "Steinerne Mörserschalen aus Patara", AA 2002, Heft 1, 233-245.

K. Parlasca, "Griechische-römische Steinschalen aus Ägypten”, Das Romisch-Byzantinische Ägyten. G. Grimm (derl.), Aegyptiaca Treverensia 2, 1983, 151-160.

D. Pinkwart, Persytlhäuser westlich der unteren Agora. AvP XIV (1984).

D. M. Robinson, Excavations at Olynthus II: Architecture and Sculpture: Houses and Other Buildings (1930).

J. F. Salles - M. J. Chavane, "Les Petits Objects" Les nivaeux hellénistiques. Kition-Bamboula IV. J. F. Salles (derl.) (1993).

R. Stuppereich, "Neugefundene Bruchstücke von Marmorplastik in Assos", Ausgrabungen in Assos 1981-1989, Ü. Serdaroğlu - R. Stüppereich - E. Schwertheim (derl.), AMS 2, 1990, 29-34.

T. Takaoğlu, "Early Cycladic presence in central-western Anatolia: evidence of stone bowls" Anadolu/Anatolia 25, 2005, 65-72.

M. Tombul, "Troas Bölgesi Hellenistik ve Roma Dönemi taş kapları”, T. Takaoğlu (ed.), Anadolu Arkeolojisine Katkellar: 65. Yaşında Abdullab Yaylah'ya Armağan (1996) 254-262.

R. Tölle-Kastenbein, Das Kastro Tigani. Die Bauten und funde griechischer und Byzantinischer Zeit. Samos XIV (1974).

Th. Wiegand - H. Schrader, Priene: Ergebnisse der Ausgrabungen und Untersuchungen in der Jahren 1895-1898 (1904). 


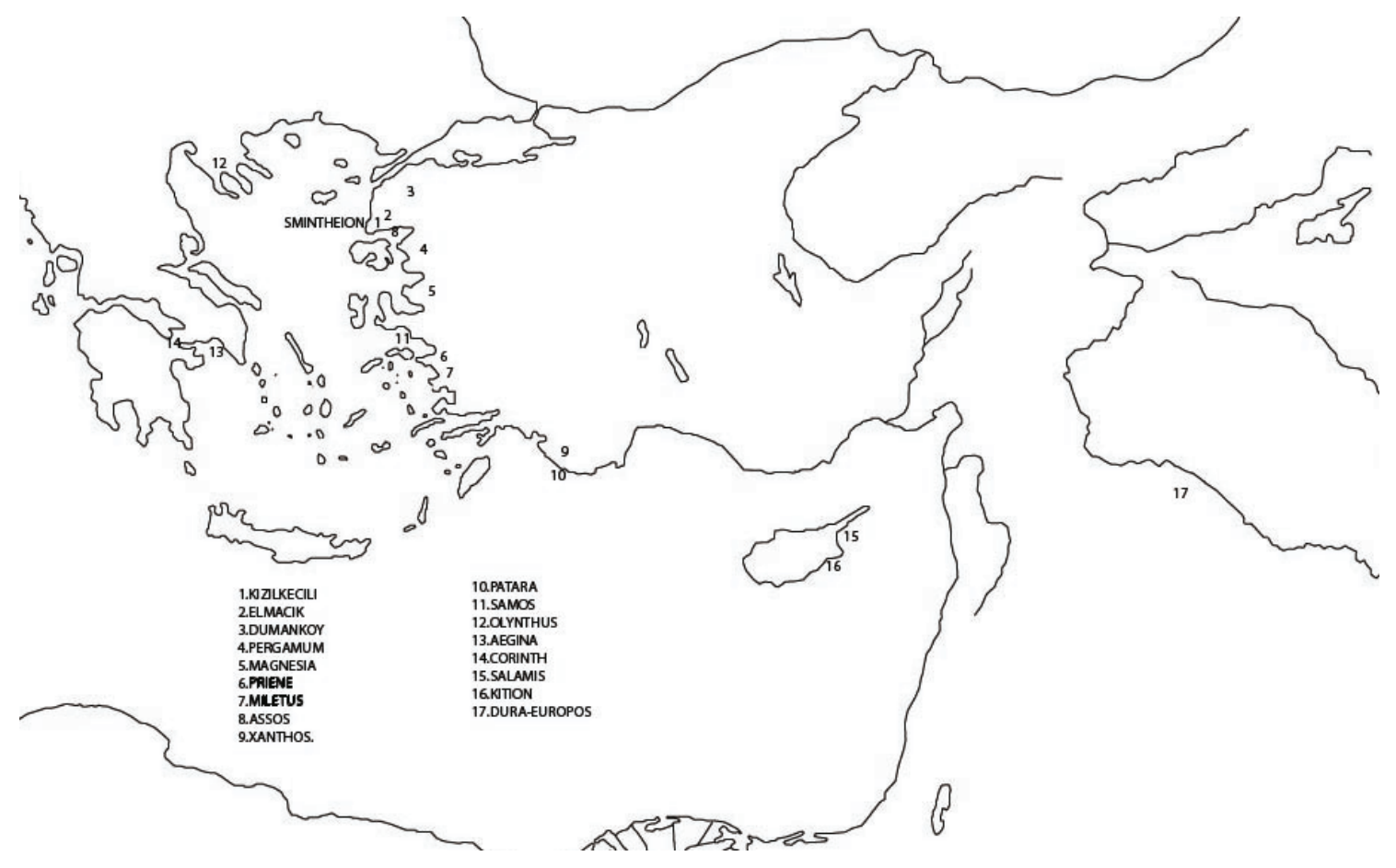

Figure 1

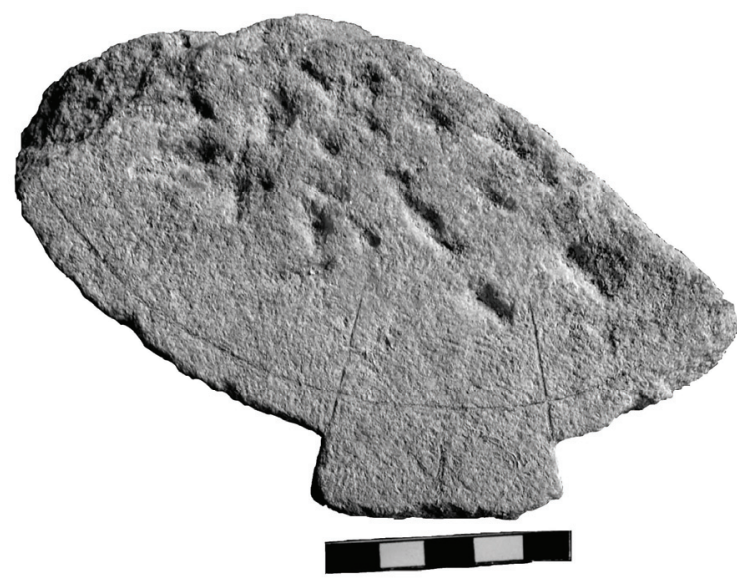

Figure 2a

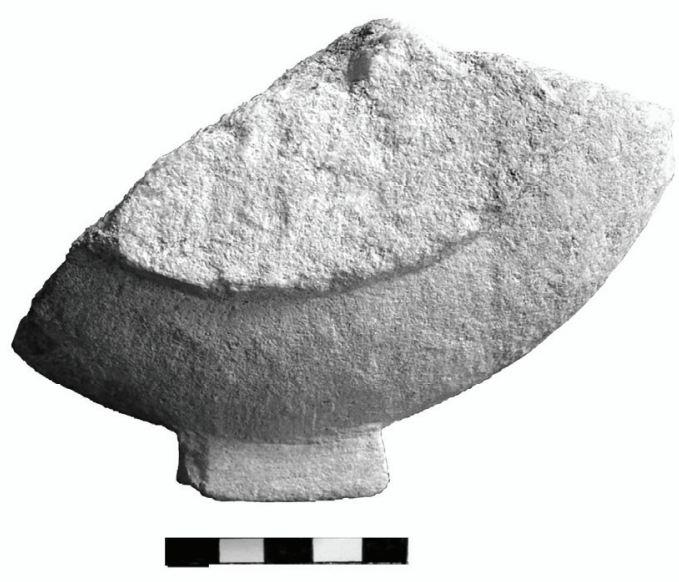

Figure 2b 


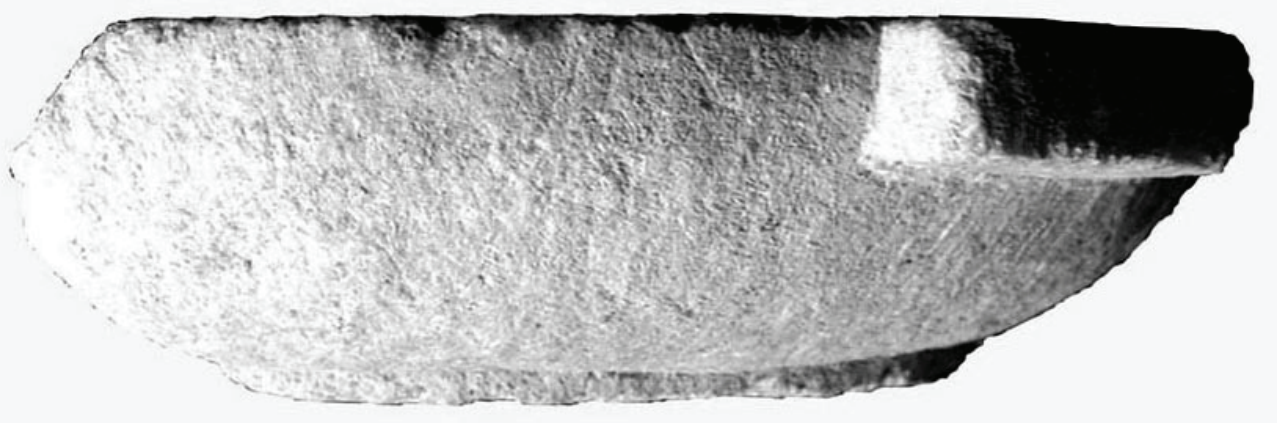

Figure 2c

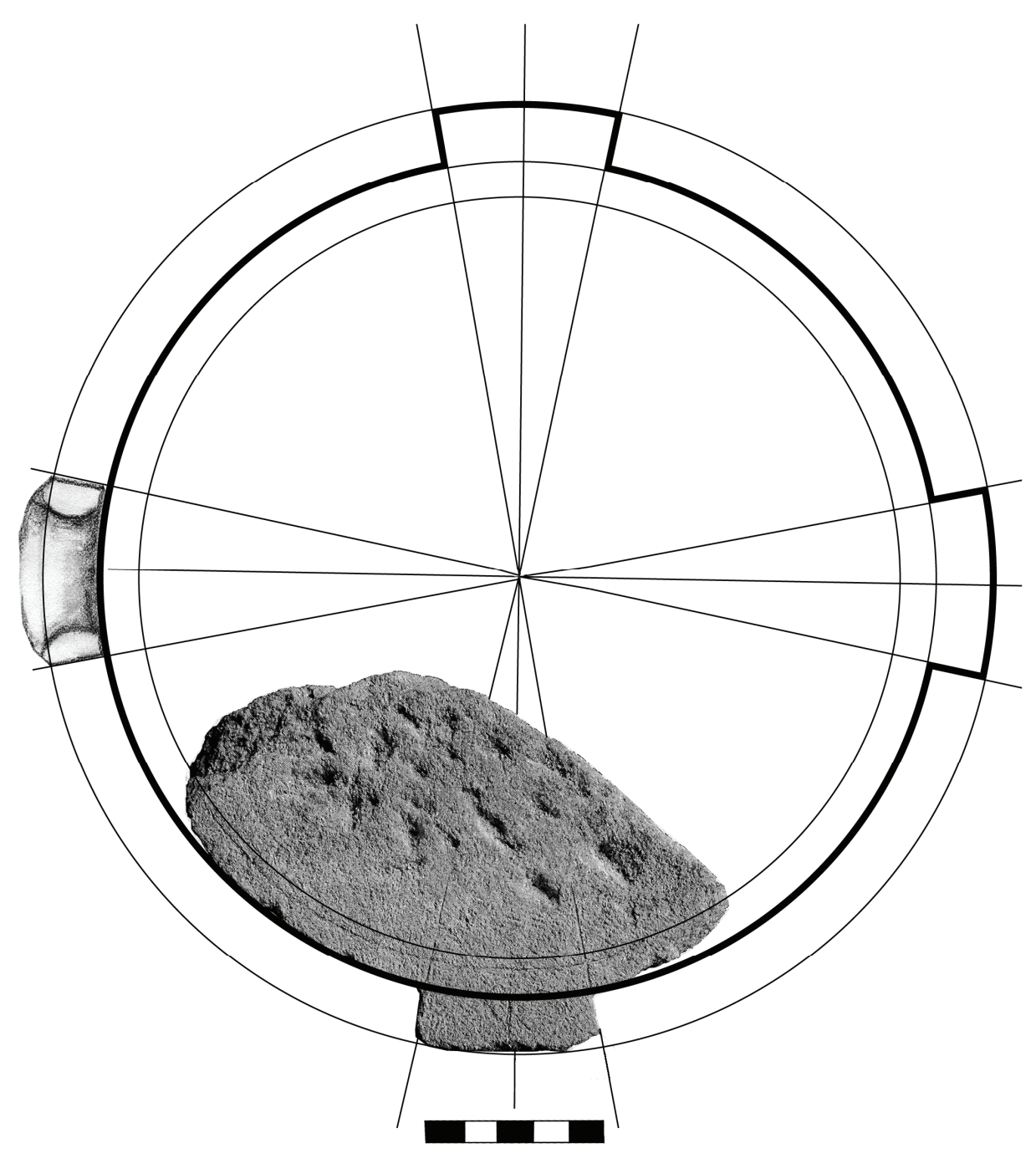

Figure 3 